ANNALES

UNIVERSITATIS M A R A E C URIE-SKŁODOWSKA

LUBLIN - POLONIA

VOL. XXXIV, 1

SECTIO J

2021

Pedagogical University of Krakow. Teachers’ Training Centre

MAŁGORZATA MĄDRY-KUPIEC

ORCID: 0000-0002-7064-9484; malgorzata.madry-kupiec@up.krakow.pl

\title{
Openness of Teachers in Relationships with Students
}

Otwartość nauczyciela w relacji z uczniami

How to QUOTE THIS PAPER: Mądry-Kupiec, M. (2021). Openness of Teachers in Relationships with Students. Annales Universitatis Mariae Curie-Skłodowska. Sectio J, Paedagogia-Psychologia, 34(1), 35-44. DOI: 10.17951/j.2021.34.1.35-44.

\begin{abstract}
The article discusses the issue of openness of teachers to themselves, which has been disregarded so far. Even though this type of openness may seem obvious, it is actually not. The phenomenon determines level of revealing the "self" of teachers in relationship with students, as well as the openness to students as such. The openness to oneself is the access to one's own thoughts, feelings, opinions, etc., which becomes a starting point for a further analysis, self-discovery and discovery of others. This issue of a key importance is investigated in the context of personal statements of a teacher, the Johari Window and the openness of teachers to students. The coined term "listening openness" is especially noteworthy in such a case. Due to its accessibility, it expresses unqualified recognition of students and following them attentively triggered by curiosity about the natural abilities of students. This kind of openness of teachers constitutes an invitation to openness for students.
\end{abstract} openness

Keywords: openness; personal statements; openness to oneself; the Johari Window; listening

\section{INTRODUCTION}

A teacher's success at work is largely determined by the ability to establish and maintain good relationships with students. They are substantial in this profession. Openness plays a significant role in building good relationships with children, apart from a dozen important qualities such as respect or positive attitude. It can shape the formal role of teachers and emphasise their individualism, so that teachers would no longer be only a source of knowledge or a database for students. 
The aim of the article is to inspire discussion and research on the category of teachers' openness to themselves. This type of openness is a starting point for openness of a pedagogue in a relationship with students and to students themselves. Therefore, it is an important factor in building good connections with students, especially because it fosters increase of self-awareness which is so indispensable in teachers' work. This study is an inspiration to discuss the mentioned topic and to undertake research in the discussed category.

\section{OPENNESS}

Generally speaking, openness is the best and the most direct form of self-help in understanding oneself and in helping others in understanding us. Undoubtedly, it is associated with revealing and discovering because it means "revealing own thoughts, feelings and reactions to a certain situation and conveying this information from the past, which is important to understand a person in the present" (Johnson, 1992, pp. 24-25). Revealing oneself refers to a less or more personal sphere of a person's life. However, it is not telling everything about oneself or revealing intimate details of one's life. A complete lack of limits in externalising own reactions may be a serious obstacle in interpersonal contacts as well as excessive and rigid limits.

Appropriate proportions in this area depend on the aim of the openness, situation, incident, words used, reactions or emotions expressed by people being in touch with each other. These factors make us become open in different ways to different people, so the range of our openness is changeable. It does not mean lack of honesty in interpersonal relationships, but it emphasises a different degree of readiness to be open to others also determined by the length of a relationship and trust. "Openness should be appropriate to the nature of the relationship with the other person, it should be a constant part of what happens between people rather than something random" (Samujło, Sokołowska-Dzioba, 2015, p. 443).

Sometimes someone's sociability creates the appearances of openness, because, by making and maintaining contact easily, sociable people can discuss the subjects totally not related to themselves. However, revealing oneself is connected with one's own authenticity and emphasises the significance of the openness to oneself.

\section{OPENNESS TO ONESELF}

The idea of focusing on the openness to oneself was born under the influence of findings on empathy of Goleman (1997) as well as pedagogic-psychological work of the author with children, parents and teachers. The openness is here considered a separate term, however, it is close to awareness, though not the same. The openness can be the introduction to awareness, or it can coexist in the process of awak- 
ening. Self-awareness, in turn, opens the door to self-discovery, self-acceptance and building trust in oneself. This interdependence is not linear, on the contrary, it happens to be more complex when we take into consideration the influence of external or specific factors for a certain person. This issue is only mentioned because it requires a separate discussion due to its significance.

An analysis of the text and experiences gained through providing help to children and adults attracted attention of the author to the role and importance of the openness to oneself in the context of revealing information about oneself and the openness to others in interpersonal relationships.

The starting point for a conversation with oneself becomes the perception and admission of various information coming from the outside and inside as well as the accompanying emotions. These seem to be key questions: How open am I to myself? Do I let all the information inside? Are there any topics that I do not discuss with anyone, even with myself? Do I have any prejudices or concepts before I begin the discussion with myself? Do I analyse this information and do self-reflection?

The answers to these questions allow better understanding of one's openness in relationships as well as the openness of others to us or its lack. They indicate a kind of access to oneself which allows self-discovery, self-acceptance and building self-identity. This is because the openness to one's own opinions and emotions means that we can analyse them, balance them against other experiences, draw up a synthesis, make conclusions, remarks, etc. At the same time, we gain knowledge about ourselves and, thanks to the reflection, we can increase our self-awareness by deciding whether to keep or reveal such information. Nevertheless, greater accessibility to oneself means a better opportunity to reveal information about oneself to others and, at the same time, an invitation to openness.

It is worth to notice that the lack of openness to oneself in interpersonal relationships can result in noticing, both in oneself and in others, certain behaviours, situations, emotions, disregarding them, underestimating or focusing on them. This, in turn, can lead to prejudices or self-fulfilling prophecy. This is illustrated by two situations from practice of the author:

- first situation: a parent who shouts at his/her child blames his/her for being aggressive, the parent does not seek contact with the child, who is withdrawn and eats meals in his/her room;

- second situation: a student uses swearwords and is aggressive during a lesson after which a teacher asks the student what he/she as an adult did wrong, the situation repeats itself during each lesson.

In the first case, the parent does not see his/her own aggression. In the second one, the teacher focuses too much on treating the student well, feeling guilty of the whole situation at the same time. However, both cases indicate the lack of adults' access to their own aggression and anger. An adult who does not see aggressive behaviours in his/herself, is astonished seeing symptoms of aggressive behaviours 
in his/her child. At the same time, the adult forgets or does not know that a child learns best by modelling-in such a case the parent is a role model.

The same shall apply in the second situation, where the teacher cannot cope with the student, moreover he/she puts the blame on him/herself - it masks his/ her anger, which is aptly read and repeated by the student. In such a case noticing and opening to own anger can give rise to a process of changes - awakening of self-awareness. As a result an analysis of situations takes place. It evokes present and past emotions and confronts them with the present state. What is necessary in this process is the readiness of the adult to open themselves as a kind of mental maturity or the mental readiness to cope with the difficulty. Nevertheless, this process, which takes place inside a person, leads to creating a better relationship with themselves and others.

\section{OPENNESS OF TEACHERS TO THEMSELVES IN A RELATIONSHIP WITH STUDENTS}

What is characteristic about the openness of teachers to themselves? What distinguishes it from the openness of people of other professions? The answer seems to be - nothing, but a more detailed analysis shows fundamental differences. They refer to the character of work as a teacher, mainly to constant contact with children and teenagers, the ability to build and maintain relationships with students and to the coping with difficult situations. Working with young people is a privilege of being a teacher. Teachers continuously deals with their creativity, spontaneity, happiness, but also with unbridled negative emotions as well as problems of such stage of life.

There is a big likelihood that teachers will be voiced in contact with children students, children inside. Especially the one that has experienced difficulties, suffering which have not been solved or sorted out yet. Then, different students' behaviours, which seem to be similar to these experienced by teachers being their age, can disrupt the relationship with a student making it ineffective and very problematic.

In the area of transactional analysis we speak about the so-called contamination of an adult by a child (Mądry-Kupiec, Kwatera, 2017), when the state I-child can recreate a situation similar to the childhood one and cause experiencing the same emotions which were felt then (Harris, 1987).

The contamination of an adult by a child in a teacher can be manifested by taking the role of a partner aimed at cooperation with a student resulting in:

- lack of rational analysis of educational situations and students' behaviours;

- making unpredictable decisions and taking unpredictable actions;

- unfair assessment and treatment of students;

- focusing on being liked and accepted by a students which causes the opposite effect: chaos in experiences and actions of both teachers and students. (Mądry-Kupiec, Kwatera, 2017, p. 96) 
Additionally, a symptom of these kinds of problems can be direct and frequent verbalisation of difficulties by teachers themselves, who does not deal with student/ students, or difficulty with a certain teacher experienced by the child. Another signal can be prejudices, irritability and presumptions of teachers. Teachers often search for reasons of such problems in students or an external situation, they analyse various explanations, which are often far from the truth, not realising that the key is in themselves.

Korczak (1958) rightly points out that only a mature child in an adult ensures a good relationship with students, which becomes possible on the basis of teachers' self-awareness. Therefore, the author calls for the necessity of work on the child inside of people who want to work with children. In turn, Samujło and Sokołowska-Dzioba (2019) in their research indicate the importance of adults' openness in relation with children, adolescents as well as with students.

It is essential for teachers to give proper attention to themselves always when they come across difficulties in relationship with students or attitude, thinking, evaluation of a child. The teachers should ask themselves the following questions: How far what is happening concerns me directly? How did I behave as a child in a similar situation and what did I feel? Did anyone treat me badly then? etc. Answering such questions allows teachers to confront themselves with emotions in order to understand the suffering of the child inside them and let it become mature.

The openness to oneself in the work of teacher is also the knowledge of one own skills, and, at the same time, deficiencies in making and maintaining good relationships with children. It particularly refers to abilities to set limits, noticing effect of the first impression and self-fulfilling prophecy.

The limits, being invisible symbolic fences, protect our inner world ensuring its integrity, supporting our identity and, above all, giving us a sense of security. Clearly set limits allow us to take responsibility for our thoughts, feelings and actions without blaming other people (Mellody, 1993). Teachers set the limits by specifying the requirements concerning the subject taught and the rules of behaviour in the lesson. In this way, teachers build trust and a sense of security in their students. "The set limits become some sort of a code of conduct governing not only relationships between teachers and students, but also the mutual relationships between the members of a group" (Kowal, Mądry-Kupiec, 2015, p. 106).

A very important aspect is also the openness of teachers to the effect of the first impression and self-fulfilling prophecy. Knowledge of the pedagogues in this topic and its reference to their own way of perceiving children, their evaluation and predicting the consequences of their own actions will allow teachers to avoid labelling students and favouring some of them.

When it comes to teachers, very important matters in maintaining relationships with students are: respect, kind approach to students and curiosity about people. If teachers require respect from students, but does not respect them themselves, this 
is the symptom of the lack of respect of teachers to themselves. The same situation applies to the kind approach and curiosity about others. Due to the lack of these qualities at adults, students show neither kindness nor curiosity. Then, opening adults to their own deficiencies or mistakes can be the first step in the course of changes.

Therefore, questions can be asked what a difficulty means for teachers, what its definition is, and how teachers behave in difficult situations. These are other important questions in the context of the analysis of the openness of teachers to themselves, the answers which can reveal important aspects of the thinking and acting of teachers towards students.

\section{PERSONAL STATEMENTS AS A FORM OF OPENNESS IN A RELATIONSHIP WITH STUDENTS}

Being open to oneself makes it easier for teachers to speak about themselves to others because knowing themselves, they know who they are talking about and what they can reveal. The best form of talking about oneself is personal statement, so called I-messages (Gordon 1997). "I-messages are applicable when the problem is at the side of the teacher, when teacher wants to exact something from student or when the problem is student-side and teacher cannot look to it at the very moment" (Sakowska, Sikora, Żwirblińska, 2003, p. 49). It can also be used when we do not find a way to communicate with a child. However, "in order for a message to be considered revealing oneself, it needs to be rather intentional than random or unconscious" (Morreale, Spitzberg, Barge, 2019, p. 121). Then, revealing oneself provides information concerning the self of a person.

Gordon (1997) claims that a well-created I-message should consist of three elements:

- the information about the student's behaviour: e.g. "When you swear during the lesson...";

- the description of the consequences of this behaviour: e.g. " ...you are disturbing me and the others";

- the description of the teachers' feelings: e.g. " ... and I feel very disappointed". This example seems to be rather formulaic and sometimes difficult to apply because including all of these three points requires a great focus and proper phrasing. It would be pointless if teachers following this example lose their spontaneity in a relationship with children, not getting the intended result. Therefore, it is essential for teachers to use personal statements in harmony with themselves so that they are sincere and authentic, relevant to the situation and students because revealing themselves too much, as well as its lack, blocks out students from relationships with teachers. In this respect, teachers need to remember that the power of I-messages lies in the fact that they allow for informing students how their behaviour influences teachers and their feelings. This message, instead of 
having an evaluating character, gives students information about what is happening with teachers (Sakowska, Sikora, Żwirblińska, 2003). It refers to freedom and another person's good will (Sujak, 2006). And students, not being evaluated, do not withdraw from the contact and do not deny it as it is in case of you-messages (Mądry-Kupiec, 2012).

Teachers in personal statements have the full right to reveal the thoughts and feelings in a certain situation towards students because they are talking about themselves. Therefore, they can talk about their negative emotions, what they do not like or do not agree with, and about what suits them. In this way, they do not harm anyone's feelings, take responsibility for the words they say, and the consequences related to them. In this way, they become clear and legible for students, and what they need is the truth not pretending. Thus, teachers become the point of reference for students, when it comes to communication. This means that students will respond to certain style of the teachers' communication, having an opportunity to follow or criticise it. Nevertheless, "communicating in this way becomes an invitation for others to react to our feelings and concerns and, perhaps, to a voluntary change of their own behaviour" (Stewart, 2019, p. 261). Owing to this, children learn that having the right to express oneself, we have the right to change ourselves, not others. And the change in us often results in a change in others.

Usually we shrink from revealing our own vulnerability when we do not want to throw off the mask of "a tough man" because we are afraid that without it we will lose our authority and we will not control the situation. (Rosenberg, 2019, p. 148)

However, being vulnerable does not mean being weak. Revealing one's own feelings is the manifestation of unusual inner strength (Stewart, 2019), courage and taking the risk of being hurt. Sharing one's own emotions can lead to a substantial change of a typical interactive scenario where, instead of defending one's own statements, an agreement is reached.

\section{OPENNESS OF TEACHERS IN THE CONTEXT OF THE JOHARI WINDOW}

"The degree and range of openness cannot be random (...). It is desirable that the openness is related to what is currently happening inside and between people being in contact with each other" (Melibruda, 1980, pp. 290-291). This interactive model of openness is presented by the Johari Window - a diagram that is called after the names of its creators, Joe Luft and Harry Ingham. It shows four quadrants representing four kinds of the openness of teachers (also called I-openness dimension), which are formed under the influence of information both known and unknown to students and teachers themselves. The four quadrants are called: open, blind, hidden and unknown. The window is presented in the picture 1. Each 
quadrant has its own character because it contains a different type of information less or more available for teachers or students.

\begin{tabular}{|c|c|c|}
\multicolumn{1}{c|}{ Known to self } & \multicolumn{2}{c}{ Not known to self } \\
\cline { 2 - 3 } Known to others & Open area & Blind spot \\
\cline { 2 - 3 } Not known to others & Hidden area & Unknown area \\
\hline
\end{tabular}

Figure 1. The Johari Window

Source: own elaboration based on (Luft, 1984, after: McKay, Davis, Fanning, 2019).

The open area is created on the basis of information known to both teachers and students. There we can find information which is available and safe for teachers, meaning all intended actions and statements which teachers can speak freely about. On the other hand, the blind spot contains information known to students, but not to teachers. These are usually some habits, signs of bad manners, defensive mechanisms, escape strategies (McKay, Davis, Fanning, 2019). The students gather this information based on observations of different reactions and actions of the teacher, non-verbal and verbal communication. In this area, students are a treasury of knowledge about teachers.

"There appear discrepancies between the own picture of oneself and the evaluating perception by others" (Latour, 2007, p. 58). Then, in the hidden area, as the name indicates, there is very personal information. This is the knowledge which teacher share about themselves and wish to keep it private. There we will find thoughts, feelings and desires as well as content not always favourable to teachers, perhaps problematic or difficult to verbalise. In the last area, the unknown one, there is information unknown for both teachers and students, so it is unconscious, forgotten or denied.

The division into these four areas is not rigid and there is a flow of information between them. It depends on the openness of the teacher to themselves and the degree of coping with difficult topics. Therefore, the question is: how big should each kind of openness/quadrant be in the teacher profession? The answer is not unambiguous and obvious. The level of openness of teachers in a relationships with students is not a constant value and will change according to several variables important in revealing oneself: width, depth, valuing, reciprocity and relevance to the topic.

The width in revealing oneself refers to the variety of subjects that teachers can talk about with students. The depth concerns the meaning of assigned information about oneself. And valuing is a positive or negative assessment under the influence of information they have revealed about themselves. While the reciprocity in 
revealing self refers to the degree of revealing oneself and relevance to the topic of conversation because it shows if people are listening to each other (Morreale, Spitzberg, Barge, 2019). Therefore, it is advisable that the open area in the Johari Window for teachers is bigger than other areas and, at the same time, adequate to relations. The hidden and unknown area should be smaller, and the blind spot - the smallest. In this way, teachers can learn the most how they are perceived by students and such information will make them become better and better.

\section{OPENNESS OF TEACHERS TO THE RELATIONSHIPS WITH STUDENTS}

Openness of teachers to the relationship with students begins from their openness to themselves because noticing the diversity in oneself allows them to see it in others. In order to achieve maturity in assessing oneself and others and ensure one's professional development, teachers should analyse the ways of arranging their own observations. This is enabled through using one's own perspectives in creating descriptions of others or situations, slowing down process of perception and delaying assessment of students with simultaneous search for alternative ways of interpreting their behaviours (Morreale et al., 2015), as well as predicting the consequences of own actions and predicting the future. Such an approach of teachers fosters noticing in students something previously not visible. Therefore, it is essential that teachers listen to themselves, give themselves some time and attention, owing to which they will recognise their own thoughts, feelings, moods, concepts, etc. Then, they will be able to listen to students, and through better understanding of themselves, they will understand students better.

This attitude can give rise to listening openness ${ }^{1}$ - a kind of openness in which teachers, being with children here and now, express unconditional recognition towards them and follow them attentively, continuously encouraging them to be open. Such encouragement is triggered by the curiosity of natural abilities of each student (Chapman, 2016). In this kind of openness, teacher share an opportunity to see these qualities of students which they are not able to notice themselves and to formulate their observations. Then, listening through one's own openness and the openness of children takes place.

\section{REFERENCES}

Chapman, S.G. (2016). Pięć kluczy do uważnego porozumiewania się. Warszawa: Wydawnictwo Amber.

Goleman, D. (2016). Inteligencja emocjonalna. Poznań: Wydawnictwo Media Rodzina.

Gordon, T. (2014). Wychowanie bez porażek. Warszawa: WAM.

1 The term proposed for the first time by the author in this article. 
Harris, T.A. (1987). W zgodzie z sobq i z toba. Warszawa: Instytut Wydawniczy Pax. Johnson, D.W. (1992). Podaj dłoń. Warszawa: Instytut Psychologii Zdrowia i Trzeźwości.

Korczak, J. (1958). Wybór pism. Vol. 2-4. Warszawa: Nasza Księgarnia.

Latour, B. (2007). Sztuka komunikacji. Kraków: WAM.

Luft, J. (1984). Group Process: An Introduction to Group Dynamics. Palo Alto: National Press Books. Mądry-Kupiec, M. (2012). Słowa, które wpływają na komunikację nauczyciela. Ruch Pedagogiczny, 2, 29-39.

Mądry-Kupiec, M. (2015). Nauczyciel w procesie komunikacji z uczniem. In: S. Kowal, M. Mądry-Kupiec (eds.), Przygotowanie do wykonywania zawodu nauczyciela. W stronę edukacji spersonalizowanej (pp. 99-118). Kraków: e-bookowo.pl.

McKay, M., Davis, M., Fanning, P. (2019). Sztuka skutecznego porozumiewania się. Gdańsk: GWP.

Melibruda, J. (1980). Ja-Ty-My. Psychologiczne możliwości ulepszania kontaktów międzyludzkich. Warszawa: Nasza Księgarnia.

Mellody, P. (1993). Granice JA. Trudności w ustanawianiu granic funkcjonalnych. In: J. Santorski (ed.), ABC psychologicznej pomocy. Rezonans i dialog (Part 8; pp. 83-95). Warszawa: Wydawnictwo Jacek Santorski \& Co Agencja.

Morreale, S.P., Spitzberg, B.H., Barge, J.K. (2015). Komunikacja między ludźmi. Motywacja, wiedza i umiejętności. Warszawa: PWN.

Rosenberg, M.B. (2019). Porozumienie bez przemocy. O języku życia. Warszawa: Czarna Owca.

Sakowska, M., Sikora, J., Żwirblińska, A. (2003). Obyś cudze dzieci... wychowywat. Jak sobie radzić z problemami wychowawczymi w gimnazjum (i nie tylko). Kielce: Oficyna Wydawnicza Nauczycieli.

Samujło M., Sokołowska-Dzioba, T. (2015). Język otwartości w relacjach nauczyciel-uczeń. In: H. Kwiatkowska (ed.), Uczłowieczyć komunikację. Nauczyciel wobec ucznia w przestrzeni szkolnej (pp. 440-460). Kraków: Oficyna Wydawnicza Impuls.

Samujło, M.A., Sokołowska-Dzioba, T. (2019). Otwartość uczniów w relacjach z rodzicami i nauczycielami. Wychowanie w Rodzinie, 20(1), 195-206.

Stewart, J. (ed.). (2020). Mosty zamiast murów. Podręcznik komunikacji interpersonalnej. Warszawa: PWN.

Sujak, E. (2006). ABC psychologii komunikacji. Kraków: WAM.

\section{ABSTRAKT}

W artykule poruszono kwestię otwartości nauczyciela na siebie, która do tej pory była pomijana. Ten rodzaj otwartości, choć może wydawać się oczywisty, w rzeczywistości taki nie jest. Określa on stopień ujawnienia ,ja” nauczyciela w relacji z uczniem, a także otwartość na samego ucznia. Otwartość na siebie to dostęp do własnych myśli, uczuć, opinii itp. Staje się ona punktem wyjścia do dalszej analizy, odkrywania siebie i innych. Na tę kwestię jako kluczową spojrzano w kontekście osobistych wypowiedzi nauczyciela, okna Johariego i otwartości nauczyciela na ucznia. Na uwagę zasługuje sformułowane tu pojęcie otwartości na słuchanie, która ze względu na swoją dostępność wyraża niewykwalifikowane uznanie ucznia i uważne podążanie za nim, wywołane ciekawością naturalnych zdolności ucznia. Taka otwartość nauczyciela jest zaproszeniem do otwartości dla ucznia.

Slowa kluczowe: otwartość; osobiste wypowiedzi; otwartość na siebie; okno Johariego; otwartość na słuchanie 